\title{
Decentralization and Foreign Aid Effectiveness: Do Aid Modality and Federal Design Matter in Poverty Alleviation?
}

\author{
Christian Lessmann \\ Gunther Markwardt
}

CESIFO WORKING PAPER No. 3035

CAtegory 6: Fiscal Policy, Macroeconomics and Growth APRIL 2010

\footnotetext{
An electronic version of the paper may be downloaded

- from the SSRN website:

- from the RePEc website: www.SSRN.com

www.RePEC.org

- from the CESifo website:

www.CESifo-group.org/wp
} 


\title{
Decentralization and Foreign Aid Effectiveness: Do Aid Modality and Federal Design Matter in Poverty Alleviation?
}

\begin{abstract}
This paper empirically studies the impact of decentralization on foreign aid effectiveness. For this purpose, we examine a commonly used empirical growth model, considering aid modality as well as different measures of political and fiscal decentralization. Our panel estimations reveal that fiscal decentralization negatively impacts aid effectiveness, while measures of political decentralization have no significant effect or even a positive one. This result is robust for grants and overall ODA, while the growth impact of other aid types is not generally conditional on decentralization. We therefore conclude that donor countries should carefully consider how both anti-poverty instruments - foreign assistance and decentralization - work together.
\end{abstract}

JEL-Code: O10, O20, O40, H70.

Keywords: foreign aid, growth, decentralization.

Christian Lessmann

TU Dresden

Faculty of Business and Economics

Chair of Public Economics

01062 Dresden

Germany

christian.lessmann@tu-dresden.de
Gunther Markwardt

TU Dresden

Faculty of Business and Economics

Chair of Public Economics

01062 Dresden

Germany

gunther.markwardt@tu-dresden.de

This version: April 2010

We would like to thank Kai A. Konrad, Benny Geys, Heike Auerswald, Christoph Böhm and the participants of the WZB conference "Reflections on Fiscal Federalism" for helpful comments. Financial assistance from the German Research Foundation (DFG) is gratefully acknowledged. 


\section{Introduction}

Since the 1960s, more than 2 trillion US dollars have been spent on foreign aid by member countries of the OECD's Development Assistance Committee (DAC). In recent years, official development assistance (ODA) exceeded 100 billion US dollars per year. In 2010, the DAC members each intend to spend between $0.2 \%$ (USA) and $1.0 \%$ (Norway and Sweden) of their GNI as ODA. Despite this enormous effort, there are still very poor countries in the world that rely heavily on external resources. Some of the poorest countries, such as Timor-Leste or the Democratic Republic of Congo, show a share of development aid in gross national income above 50\% [Worldbank (2009)].

Against this background, a controversial discussion is held about the effectiveness of foreign aid. The major questions are whether aid promotes economic growth, and under which circumstances aid is more or less effective. A large empirical literature has emerged in the past 35 years studying this research question. The main result of this literature is that aid has no significant direct impact on growth [see, e.g., Doucouliagos and Paldam (2009a)]. However, there seem to exist particular institutional features in developing countries that make aid more or less effective. One positive feature is a 'good policy' environment, which was initially studied by Burnside and Dollar (2000). ${ }^{1}$ The conclusion from this body of literature is straightforward: give more aid to those countries that meet this criterion and help other countries to build performanceenhancing political conditions. However, the result has been criticized by Easterly (2003), Easterly et al. (2004) and others, so the literature has begun to focus on other determinants of aid effectiveness, such as geographic location [Dalgaard et al. (2004)], political stability [Islam (2005)] or rent-seeking activities [Economides et al. (2008)].

One issue that has been neglected so far is the design of the federal systems of aidreceiving countries. This is quite surprising, as national and supranational development agencies consider decentralization as a major part of their anti-poverty programs. For instance, between 1993 and 1997, around 12\% of the World Bank projects completed involved decentralizing responsibilities to lower levels of government [Litvack et al. (1998)]. The reason for considering decentralization in anti-poverty programs is that it may have a direct positive effect on economic development and growth [Oates (1972)]. Decentralization brings the government closer to the people so that local officials are better informed about the local needs and are thus better able to provide the optimal mix of local policies. This increase in efficiency contributes to economic growth [Oates (1993)]. The decentralization theorem may also be important for aid effectiveness. If local bureaucrats have better information about local needs,

\footnotetext{
${ }^{1}$ For comprehensive literature surveys, see McGillivray et al. (2006), Roodman (2007), Rajan and Subramanian (2008), Doucouliagos and Paldam (2009a), and Lessmann and Markwardt (2009).
} 
they may also have an advantage in selecting the most effective development projects to be financed by foreign aid. According to Oates, foreign aid should therefore be more effective in decentralized countries. However, the efficiency-enhancing effect of decentralization may be undermined by factors such as coordination problems, excessive regulation, administrative costs, and corruption or cronyism. These problems are much more likely to occur in developing countries than in developed ones, so the direct growth impact of decentralization is debatable, as is the impact on aid effectiveness. Assume, for example, a poor country in which local governments are formed by local elite groups. Within such a framework, it is unlikely that aid is spent effectively at the local level, as the elite groups favor spending the money at the benefit of their members instead of spending the money on the most effective projects from a growth perspective [Bardhan (2002), Bardhan and Mookherjee (2006)]. In such a situation, decentralization would decrease aid effectiveness.

We further argue that the result regarding decentralization depends on the particular federal design of aid-receiving countries as well as the aid modality. If, for example, local bureaucrats are held accountable through local elections, the efficiencyenhancing effect of decentralization may overweigh the disadvantages mentioned. Simultaneously, rent-seeking activities are much more likely to occur if the development assistance comes in the form of grants or loans instead of technical assistance. If donor countries concede technical assistance at the local level, it is much more difficult for the elites to embezzle money as in the case of a general budget, as spending decisions are influenced and controlled by the donor. In this context, Doucouliagos and Paldam state that "researchers should focus their attention away from aggregate measures of aid to more disaggregate ones." [Doucouliagos and Paldam (2009b), p. 7].

In light of these multi-faceted arguments, the aim of our paper is to investigate the impact of different types of decentralization on the effectiveness of different aid modalities. To answer this research question, we estimate a commonly used growth model based on a panel data set of 72 developing countries. In doing so, we use various indicators for fiscal and political decentralization and distinguish between alternative types of foreign aid. Our main finding is that fiscal decentralization has a negative impact on aid effectiveness, while political decentralization has no significant effect or even a positive one. The negative impact of fiscal decentralization is robust for grants and overall development assistance, while the growth impact of loans and technical assistance does not depend on decentralization. Our results have important implications for the optimal mix of anti-poverty programs, especially for those which involve decentralization.

The paper is organized as follows. Section 2 reviews the theoretical literature and discusses the impact of decentralization on the effectiveness of foreign aid. Section 
3 discusses the econometric specification and underlying data. The empirical results are discussed in section 4 , and section 5 concludes.

\section{The theory of decentralization and aid effectiveness}

Decentralization is in vogue in developing countries, at least because donor countries and international development agencies consider decentralization as an important element in their anti-poverty programs. The main argument in favor of decentralization is based on the decentralization theorem: the transfer of powers to sub-national governments increases public-sector efficiency, thus promoting economic development [Oates (1972), Oates (1993)]. Decentralized authorities are much better informed regarding local needs and can provide the economically efficient quantity and quality of local public goods. Especially in the case of a federation with heterogeneous regions, decentralized officials are in a better position to meet local demands [Oates (1972)]. Another argument in favor of decentralization is the role of local governments in preserving markets [Weingast (1995)]. The idea is that the government acts as monopolist and has the power to exploit the private sector [Shleifer and Vishny (1993)]. In a decentralized setting, local governments compete on mobile factors. This

fiscal and institutional competition limits the government's ability to extract rents, enhancing economic efficiency and thus economic growth.

The main question is how decentralization affects aid effectiveness. The efficiency argument above can also be used in this context. Local governments are better informed regarding local demands and are thus in a better position to allocate aid to the most useful projects compared to the central government. If foreign aid is aimed at overcoming the shortness of local public goods, such as infrastructure, schools, or health care, then decentralization should increase the efficiency of public services and aid effectiveness. The competition argument is also relevant in light of the limited amount of aid available in developing countries. Sub-national jurisdictions have an incentive to perform well in exchange for aid payments increasing aid effectiveness. From this point of view, decentralization should increase aid effectiveness.

However, several economic researchers deny the positive effects of decentralization for developing countries. Swaroopa et al. (2000) analyze the fungibility of aid in federal systems and find that aid merely substitutes for spending that the government would have undertaken anyway. Moreover, aid received by sub-national governments decreases central government transfers in a similar amount. From a political economy perspective, Prud'homme (1995) argues that in decentralized countries, there are more opportunities for corruption at the local level, as local politicians and bureaucrats are more likely to be subject to the pressing demands of local interest groups. In addi- 
tion, local decision makers usually possess more discretionary powers than national officials, increasing the possible negative effects of decentralization. In the same vein, Tanzi (1996) argues that local officials live closer to the citizens, and this contiguity leads to a higher impact by local interest groups on local policy outcomes. Bardhan and Mookherjee provide a formal analytical framework to investigate the effects of decentralization on the provision of public service in developing countries, considering the capture of local governments [Bardhan and Mookherjee (2006)]. With local capture, defined by an elite group receiving a larger weight in the local government's welfare function, there is a tendency for the local government to provide excessive services to the local elite at the expense of the non-elite [see also Bardhan (2002)]. ${ }^{2}$ The DAC and the aid-receiving countries identify rent-seeking and corruption as the most important obstacles for economic growth and aid effectiveness [OECD (2008)]. These problems may also occur if local bureaucrats decide on the allocation of foreign aid to local development projects. Therefore, aid may be less effective in decentralized countries due to corruption and cronyism.

The quality of bureaucrats is also an important factor for the relationship between aid, growth, and decentralization. Prud'homme (1995) and Tanzi (1996) argue that central government bureaucracies are likely to attract more qualified people because they offer better career opportunities and higher salaries [Brueckner (2000)]. If qualified individuals are abundant, as in most industrial countries, sub-national governments may have staff that is as qualified as those in national governments. In developing countries, however, educational standards are low and qualified human capital is scarce. Therefore, under decentralization, sub-national government officials entrusted with aid disposition may be less qualified for this task than central bureaucrats, reducing the effectiveness of aid. The previous discussion shows that the hypothesis regarding the relationship between aid effectiveness and the federal government structure is well grounded in the theoretical literature.

An issue not yet discussed is aid modality. Not all arguments mentioned are relevant to each type of foreign assistance. Consider, for instance, grants vs. technical assistance. Unconditional grants add to the general governments' budget, and we can easily assume that they go to lower levels of government through the budgetary process in a manner similar to that used for other kinds of revenue. Following the decentralization theorem, the growth impact of unconditional grants should be higher in decentralized countries. However, if there are corrupt or badly educated bureaucrats at the local level, the positive effect of those payments is weakened. In the past, unconditional grants have been one of the most important types of aid because debt reliefs are

\footnotetext{
${ }^{2}$ An empirical study by Lessmann and Markwardt (2010) shows that decentralization has indeed a negative impact on corruption if the monitoring of bureaucrats does not work, which is the case in most aid-receiving countries.
} 
nothing else then unconditional grants.

In contrast, technical assistance has different effects. Assume that a donor country sends development aid workers to construct schools or basic infrastructure in an aidreceiving country. In this case, decentralization should be advantageous, as local bureaucrats have better knowledge on the best location than central bureaucrats. However, most importantly, the potentially adverse effects of decentralization are less pronounced now. Most of the monetary value of technical assistance comes in the form of personnel costs and material costs accrued by the donor himself. Due to this fact, it is much more difficult to dissipate or to embezzle the money, as the monetary value cannot be transferred to personal bank accounts. Of course, local elite groups can still try to influence the donor to carry out construction at the location that is best suited for their members and in a way that involves politically connected local firms. But the problem should be less eminent as in the case of unconditional grants or loans. Our example shows, that aid modality matters in our context.

Another question to be discussed is the role of the particular federal design of aidreceiving countries in this context. The decentralization theorem requires that subnational governments have a certain amount of authorities in decision making. This aspect is measured generally by the degree of fiscal decentralization, such as the share of sub-national government expenditures in total government expenditures. However, having a high degree of fiscal decentralization does not necessarily imply that subnational jurisdictions have autonomy in decision-making. It is also possible that central governments devolve responsibilities and financial resources to local governments, but the fulfillment of tasks at the local level is defined by the central government's legislature. In this case, measures of fiscal decentralization are merely an insufficient indicator for the real autonomy of sub-national governments. It is therefore important to consider the degree of political decentralization, that is, whether local governments make spending decisions autonomously [Fan et al. (2009)]. Measures of political decentralization are also important in the context of local government accountability. In contrast to fiscal decentralization, which strengthens accountability only indirectly through inter-jurisdictional competition, political decentralization may directly impact local government accountability through local elections. If there are elections at the local level then local governments are directly accountable for their actions. In this case, the discussed negative effects of decentralization on aid effectiveness through, for example, corruption and cronyism at the local level are unlikely to occur. Our discussion shows that the theoretical literature implies that decentralization impacts aid effectiveness in one way or another. Also, both aid modality as well as the particular federal design of aid receiving countries matter in this context. The following section tests these relationships empirically. 


\section{Empirical analysis}

Our theoretical discussion suggests that the degree of decentralization in aid-receiving countries may determine aid effectiveness. Following Oates' decentralization theorem, aid should be more effective in decentralized countries and therefore stimulate more growth. At the same time, decentralization may have reverse effects, such as through increased corruption and cronyism or through poor bureaucratic quality at the local government level. Moreover, the aid modality should also have an influence on the relationship between aid, decentralization, and growth. In light of these opposing arguments, this section studies the effectiveness of aid on economic growth by considering both the degree of decentralization and the aid modality in aid-receiving countries. Our empirical work attempts to answer two key questions: (1) Is the effect of aid on growth conditional on the federal structure of aid-receiving countries? (2) Do aid modality and the federal style in particular matter in this context?

\subsection{Econometric specification}

To answer our research questions, we estimate variants of a well-established timeeffects panel data model. The basic growth regression for $N$ countries and $T$ time periods, where countries are indexed by $i$ and time by $t$, has the following form:

$$
\hat{y}_{i, t}=\alpha y_{i, t}+\sum_{j=1}^{k} \beta_{j} \operatorname{control}_{j, i, t}+\gamma_{1} \operatorname{aid}_{i, t}+\gamma_{2} \operatorname{dec}_{i, t}+\gamma_{3}\left(\operatorname{aid}_{i, t} \cdot \operatorname{dec}_{i, t}\right)+\mu_{t}+\epsilon_{i, t} .
$$

Here, $\hat{y}_{i, t}$ is the real per capita GDP growth rate, $y_{i, t}$ is the logarithm of the initial real per capita GDP at the beginning of each period, control $_{j, i, t}$ are $k$ exogenous control variables affecting growth, aid $_{i, t}$ represents aid receipts relative to GDP, $d e c_{i, t}$ represents alternative measures of fiscal or political decentralization, $\mu_{t}$ are time effects, and $\epsilon_{i, t}$ is a random error term. Our growth equation is similar to specifications often used in the literature on aid effectiveness [see, e.g., Burnside and Dollar (2000), Hansen and Tarp (2000), Easterly (2003), Easterly et al. (2004), Burnside and Dollar (2004) and many others].

Our explanatory variables are taken from the aid and growth literature rather than from the cross-country growth literature in order to achieve a better comparability of our results to existing studies. It is unusual in the aid and growth literature to include standard growth determinants such as investment or savings, as this decreases the size of the sample to an extent, which would make a serious econometric analysis impossible. Keep in mind that we are dealing with developing countries, for which we have only very poor data in terms of quantity and quality. ${ }^{3}$

\footnotetext{
${ }^{3}$ See Rajan and Subramanian (2008) for a detailed discussion of this issue.
} 
As a control variable, we allow growth during period $t$ to depend on $y_{i, t}$, the logarithm of real per capita GDP at the beginning of the period, to capture convergence effects. Moreover, our growth equation also considers $k$ exogenous control variables. These variables are necessary to capture institutional and political factors that might affect growth and help us to avoid an omitted variable bias. The first control is ethnolinguistic fractionalization, which the literature has shown to be correlated with poor growth performance. A second control is the number of assassinations, which captures civil unrest, as well as an interaction term between ethnic fractionalization and assassinations [see, e.g., Burnside and Dollar (2000)]. Third, we consider the institutional quality using a combined governance indicator. Fourth, we include inflation in our growth regressions, which serves as a proxy for macroeconomic stability. Finally, we include regional dummies for sub-Saharan countries and East Asia, as it is commonly known that Asian countries have performed well in the past, while sub-Saharan Africa continues to perform poorly. These differences are of a systematic nature, which we cannot explain by control variables other than regional dummies. Note that not all of our variables are time variant. Our measures of ethnic fractionalization, institutional quality and the regional dummies capture time-invariant heterogeneities, while the variation within these groups is explained by the initial GDP, assassinations, inflation, aid, the degree of decentralization and interaction terms. Due to these data restrictions, it is not possible to use a country fixed-effects model.

Our theoretical discussion in section 2 suggests that the effectiveness of foreign aid depends on decentralization; our growth equation thus includes not only measures of aid and decentralization but also their interactions.

We estimate variants of equation 1 using a panel across eight four-year periods from 1966 through 1997. Our data set consists of up to 72 developing countries. The bottleneck for our research is the availability of government finance data, which are required to calculate decentralization measures. This restricts our sample to a maximum of 72 countries, which decreases to a minimum of 38 countries, depending on the measurement concept of decentralization. Our set of countries is always congruent for smaller samples with the whole set of 72 countries, although we thereby lose several observations. However, always using the same sample of countries makes our subsamples comparable. The number of periods and countries in our sample implies a maximum of 480 observations. Because we have only a maximum of 381 observations in our regressions, our panel is unbalanced. 


\subsection{The data}

The GDP and inflation data are from Worldbank (2009). ${ }^{4}$ Alesina et al. (2003) provide the data for ethnolinguistic fractionalization; the number of assassinations come from the Easterly et al. (2004) data set. Our measure of institutional quality is the mean value of the three governance indicators: 'government effectiveness', 'control of corruption', and 'rule of law', provided by Kaufman et al. (2009).

Our main variables of interest are the measures of development, foreign aid and decentralization. In line with the literature, we use the real GDP per capita growth rate as a measure of economic development. Our measures of foreign aid are extracted from the OECD DAC database. We thus refer to the official development assistance (ODA) rather than to measures of effective development assistance (EDA). The main difference between EDA and ODA is that EDA is the sum of grants and the grant equivalents of official loans, whereas ODA includes both the direct grants and concessional loans for which the grant component is above $25 \%$. Which measure to use and whether it should be used in current or constant U.S. dollars is widely discussed in the literature [see, e.g., Chang et al. (1998)]. In the end, it should not make any difference in our context, as Dalgaard and Hansen (2001) have shown that the Pearson correlation between nominal ODA/GDP and nominal EDA/GDP is 0.98 , and the correlation between nominal ODA/GDP and real EDA/GDP is 0.95 [see also Roodman (2007)]. We decided to use the nominal ODA/GDP ratio, allowing us tu use one additional four-year period in our panel.

The theoretical discussion has shown that aid modality should matter in the aiddecentralization-growth nexus. We therefore distinguish between five different aid types (each as share of GDP): grants, loans, technical assistance, humanitarian aid, and total net ODA. A meaningful measure to compare the relevance of the different aid types is to relate them to the total net ODA. We thereby find that at the end of the 1990s, which is our last observation period, about $88 \%$ of the total net ODA was composed of grants, while $12 \%$ was spent as loans (net). About one third of the total net ODA is classified as technical assistance. This aid type includes development assistance in terms of building up local infrastructure, schools, or health care, and it incorporates the public advisory of the government in general, which also includes expenditures in donor countries. This is why technical assistance cannot be declared as the provision of local public goods, as one might first presume. Humanitarian (food) aid amounts to only $3 \%$ of the total net ODA. Aside from these different spending categories, we are also able to distinguish between bilateral and multilateral aid. This distinction might also be important in the aid-growth nexus, as single countries may

\footnotetext{
${ }^{4}$ See Table A.1 in the appendix for details. Table A.2 provides summary statistics of all considered variables.
} 
be self-interested in their development policy [see Annen and Kosempel (2009)].

The last variables to be discussed in detail are our measures of decentralization. Several measurement concepts are used in the literature [see, e.g., Treisman (2002) and Rodden (2004)]. We have seen from our theoretical discussion that the particular federal design of aid-receiving countries should matter for aid effectiveness. In general, decentralization is viewed as the devolution of authority towards sub-national governments, with total government authority over society and economy perceived as fixed. Attempts to define and measure decentralization have focused on fiscal authority rather than political authority. In our context, we are interested in both issues. First, we need an indicator capturing whether aid is spent on the central or local level, and second, we need a measure capturing whether local governments are involved in the decision-making process, which assigns aid to particular projects.

The first issue can be approximated by using measures of fiscal decentralization, which can be calculated from the IMF Government Finance Statistics. The IMFGFS includes budgetary data on more than 60 aid-receiving countries. Those measures include the degree of expenditure decentralization (EXPDEC) and the degree of revenue decentralization $(R E V D E C)$, which relate expenditures (revenues) of subnational governments to total government expenditures (revenues). The problem with the IMF data is that it does not cover our whole observation period, which starts in 1966. The GFS data starts in the 1970s, and there are many missing values. We thus compute the average of decentralization measures between the years 1966 and 1997 and we thereby lose the time-series properties of the decentralization data, but we are able to substantially extend the number of observations in our estimations. Both measures are commonly used in the literature on decentralization and growth [see, e.g., Davoodi and Zou (1998), Zhang and Zou (1998), and Woller and Phillips (1998)]. However, these indicators do not necessarily reflect sub-national government autonomy in decision-making, as the central government may also determine spending at the local level through central government legislation. To capture these effects, a commonly used measure based on budgetary accounts is that of so-called vertical imbalances (VERTIMB). This measure relates central government transfers to sub-national government expenditures and is therefore a measure of the transfer dependency of sub-national governments. Note that a high value of this measure indicates little local autonomy, while all other decentralization measures we use are defined such that a high value represents a high degree of decentralization. A final measure of fiscal decentralization reflecting local government autonomy is the degree of tax decentralization, which relates the tax revenues of sub-national governments to total government revenues $(T A X D E C)$. This is an alternative fiscal indicator of sub-national government autonomy. These measures are imperfect to the extent that 
they do not reflect the political dimension of the underlying decision-making process. Assume, for example, that the central government determines the tax base and that sub-national governments determine the tax rate. In this case, the tax decentralization index might indicate a high degree of autonomy, although the central government has the major influence on sub-national revenues.

To capture the dimension of political decentralization, we refer to decentralization measures provided by Daniel Treisman [see Treisman (2002) and Fan et al. (2009)]. The data set is built on earlier work on the operationalization of federalism by Lijphart (1984), Elazar (1995), and others. A first measure of political decentralization is a dummy variable for those countries that have a federal constitution (FEDERAL). ${ }^{5}$ Only 8 out of the 72 countries in our sample are classified as federal, so the variance of this measure is not very high. Nevertheless, higher variance is provided by the measure for the number of vertical government tiers (TIERS), which ranges from 1 to 6 by definition. In our sample, the range is between 2 (Trinidad and Tobago) and 6 (Uganda and Senegal). This measure is important to test for double-marginalization effects in decentralized systems [Shleifer and Vishny (1993)]. Treisman's data also contain data on local elections, which are important for testing electoral accountability arguments. One measure is a dummy variable that takes the value one if there are elections at the lowest government level; a second dummy variable, takes the value one if there are elections at the second-lowest government level. We combine these measures to a new dummy variable indicating whether there are elections at any subnational level of government (BOTEL). In the context of local government efficiency it is very important to also include a measure of local autonomy. For this purpose, Treisman creates several dummy variables based on the constitutions of countries. A sub-national legislature is said to have 'residual authority' if the constitution assigns the exclusive right to legislate on issues that are not specifically assigned to one level of government (RESID). Another measure captures the 'autonomy' of a sub-national legislature. It is said to exist if the constitution reserves exclusive decision-making power on task considered (AUTON).

In addition to the measures of fiscal and political decentralization, we use the share of sub-national government employment in total government employment as a further decentralization indicator (SUBEMPL) which cannot be assigned to either of the two categories. The necessary data on public sector employment are provided by the International Labor Organization's (ILO) LABORSTA database. This decentra-

\footnotetext{
${ }^{5}$ The following criteria have to be fulfilled to be counted as a federal country: a country has at least two levels of government that which share parts of the executive and legislative authority; the sub-national governments have representation in the federal parliament (second chamber); there is a duty to obtain consent on constitutional amendments; a constitutional jurisdiction solves disputes between organs of state; institutions foster collaboration [see Watts (2008)].
} 
lization measure is essential for testing the hypothesis that decentralization increases corruption and cronyism, as local bureaucrats have more opportunities for face-toface interactions with firms and individuals than their central counterparts [Bardhan (2002), Prud'homme (1995)]. From this perspective, countries with a greater share of public-sector employees located at sub-national levels may be more corrupt, and foreign aid may thus be less effective. At the same time, a greater share of sub-national government employment increases the probability of being detected in corrupt activities and embezzlements so that the sign of the net effect is ex ante ambiguous. We use all discussed decentralization measures to test the impact of decentralization on the aid-growth nexus.

\subsection{Estimation results}

In the following, we test our hypothesis that the relationship between foreign aid and growth is conditional on the degree of decentralization and that both aid modality as well as federal style matter in this context. The data on 7 aid types and 10 different decentralization measures imply 70 regressions without testing for endogeneity and robustness. This is definitely more information than we can present in detailed tables containing regression coefficients and diagnostics. We thus decided to discuss one result in detail, which helps the reader to understand the underlying methodology and potential threats. All other results are summarized in table 2 at the end of this section.

Table 1 presents the estimation results including the degree of expenditure decentralization $(E X P D E C)$ and the total net ODA. In column (1), we show OLS estimations without interaction of aid and the decentralization measure; in column (2), we added the interaction term $(O D A \times E X P D E C)$ to address whether the effectiveness of total net ODA depends on the degree of expenditure decentralization. In the following two columns, we repeat these estimations by applying the two-stage least-squares (TSLS) estimation procedure instrumented for foreign aid by its one-period (four-year averaged) lagged values, as donor countries might respond to negative growth shocks by providing more assistance. In this case, aid is influenced by growth, and we would have an endogeneity bias. Our instrumentation strategy follows Burnside and Dollar (2000), Dalgaard and Hansen (2001), and others.

The estimation without the interaction of aid and decentralization (column 1) shows that the degree of expenditure decentralization is positively associated with economic growth for our sample of developing countries. This result is in line with the theoretical predictions [see, e.g., Oates (1972)] and previous empirical findings [see, e.g., Iimi (2005)]. Noteworthy is that foreign aid has a significant negative impact on growth 
in the OLS regressions, while the effect disappears when controlling for endogeneity. Again, this result is supported by the majority of literature, which finds no significant direct effect of aid on growth [see, e.g., Burnside and Dollar (2000), Easterly (2003), Easterly et al. (2004), and others].

Table 1: Estimation results: Expenditure decentralization and total net ODA

\begin{tabular}{|c|c|c|c|c|}
\hline & \multicolumn{4}{|c|}{ Dependent variable: real GDP growth } \\
\hline & \multicolumn{2}{|c|}{ OLS } & \multicolumn{2}{|c|}{ TSLS } \\
\hline & $(1)$ & $(2)$ & $(3)$ & $(4)$ \\
\hline \multirow[t]{2}{*}{ initial GDP } & -0.018 & -0.012 & -0.005 & 0.002 \\
\hline & $(-1.07)$ & $(-0.71)$ & $(-0.29)$ & $(0.10)$ \\
\hline \multirow[t]{2}{*}{ ethnic fractionalization } & -0.022 & -0.010 & 0.002 & 0.020 \\
\hline & $(-0.66)$ & $(-0.32)$ & $(0.06)$ & $(0.59)$ \\
\hline \multirow[t]{2}{*}{ assassinations } & -0.015 & -0.017 & -0.017 & -0.019 \\
\hline & $(-1.01)$ & $(-1.14)$ & $(-1.08)$ & $(-1.23)$ \\
\hline \multirow[t]{2}{*}{ ethnic $\times$ assassinations } & 0.011 & 0.009 & 0.021 & 0.017 \\
\hline & $(0.30)$ & $(0.27)$ & $(0.57)$ & $(0.49)$ \\
\hline \multirow[t]{2}{*}{ governance } & $0.046^{* * *}$ & $0.044^{* * *}$ & $0.048 * * *$ & $0.046^{* * *}$ \\
\hline & $(3.03)$ & $(3.06)$ & $(2.95)$ & $(3.13)$ \\
\hline \multirow[t]{2}{*}{$\log (1+$ inflation $)$} & $-0.073^{* * *}$ & $-0.079 * * *$ & $-0.079^{* * *}$ & $-0.087 * * *$ \\
\hline & $(-3.64)$ & $(-3.91)$ & $(-3.64)$ & $(-4.08)$ \\
\hline \multirow[t]{2}{*}{ Sub-Saharan Africa } & -0.013 & -0.011 & $-0.041^{* *}$ & $-0.037^{*}$ \\
\hline & $(-0.56)$ & $(-0.46)$ & $(-2.14)$ & $(-1.93)$ \\
\hline \multirow[t]{2}{*}{ East-Asia } & $0.096^{* * *}$ & $0.097^{* * *}$ & $0.105^{* * *}$ & $0.103^{* * *}$ \\
\hline & $(8.44)$ & $(8.67)$ & $(8.29)$ & $(8.17)$ \\
\hline \multirow[t]{2}{*}{ expenditure decentralization } & $0.001^{*}$ & $0.002^{* * *}$ & $0.001^{* *}$ & $0.002^{* * *}$ \\
\hline & $(1.78)$ & $(3.03)$ & $(2.25)$ & $(4.01)$ \\
\hline \multirow[t]{2}{*}{ total net ODA } & $-0.895 * * *$ & -0.374 & -0.168 & 0.463 \\
\hline & $(-2.87)$ & $(-0.94)$ & $(-0.43)$ & $(1.00)$ \\
\hline \multirow[t]{2}{*}{ expenditure decentralization $\times$ ODA } & & $-0.034^{* * *}$ & & $-0.044^{* * *}$ \\
\hline & & $(-2.92)$ & & $(-3.75)$ \\
\hline Period dummies & yes & yes & yes & yes \\
\hline Obs. & $246(46)$ & $246(46)$ & $214(44)$ & $214(44)$ \\
\hline adj.- $R^{2}$ & 0.31 & 0.32 & 0.33 & 0.35 \\
\hline
\end{tabular}

All $t$-statistics reported below the coefficient estimates are based on robust standard errors [see Beck and Katz (1995)]. Significance levels are reported as follows: * for a 90\%-significance-level, ** for $95 \%$ and $* * *$ for more than $99 \%$.

As we are primarily interested in the impact of fiscal decentralization on aid effectiveness, we focus on the specification using the interaction term. Column (2) shows that the coefficient of our decentralization measure is significant and positive, the coefficient of aid is insignificant, and the coefficient of the interaction term is significant and negative. However, we are not particularly interested in the individual statistical significance of either of these terms. Instead, we want to know their joint significance or, more correctly, the marginal effect of aid on growth. ${ }^{6}$ The marginal effect can be

\footnotetext{
${ }^{6}$ For an excellent overview on do's and don'ts in interaction models, see Brambor et al. (2006).
} 
calculated by the derivation of equation (1) with respect to the aid term:

$$
\frac{\partial \hat{y}}{\partial a i d}=\gamma_{1}+\gamma_{3} \cdot d e c
$$

The interaction model implies that the effect of a change in aid on growth depends on the value of the conditioning variable decentralization. While it is possible to calculate the marginal effect using equation 2 and the results obtained in Table 1 , it is not possible to do likewise for the standard errors. The standard error of interest is:

$$
\hat{\sigma}_{\frac{\partial \hat{y}}{\partial a i d}}=\sqrt{\operatorname{var}\left(\gamma_{1}\right)+\operatorname{dec}^{2} \cdot \operatorname{var}\left(\gamma_{3}\right)+2 \cdot \operatorname{dec} \cdot \operatorname{cov}\left(\gamma_{1}, \gamma_{3}\right)} .
$$

The standard errors are used to calculate the confidence bands around the marginal effects. To help the reader see more precisely how the marginal effect of aid on growth varies by the degree of expenditure decentralization in developing countries, this marginal effect is plotted in Figure 1. Note that we refer to results we receive using the TSLS estimation procedure (column (4)). The figure also includes confidence bands for the 1 and 10 percent significance levels.

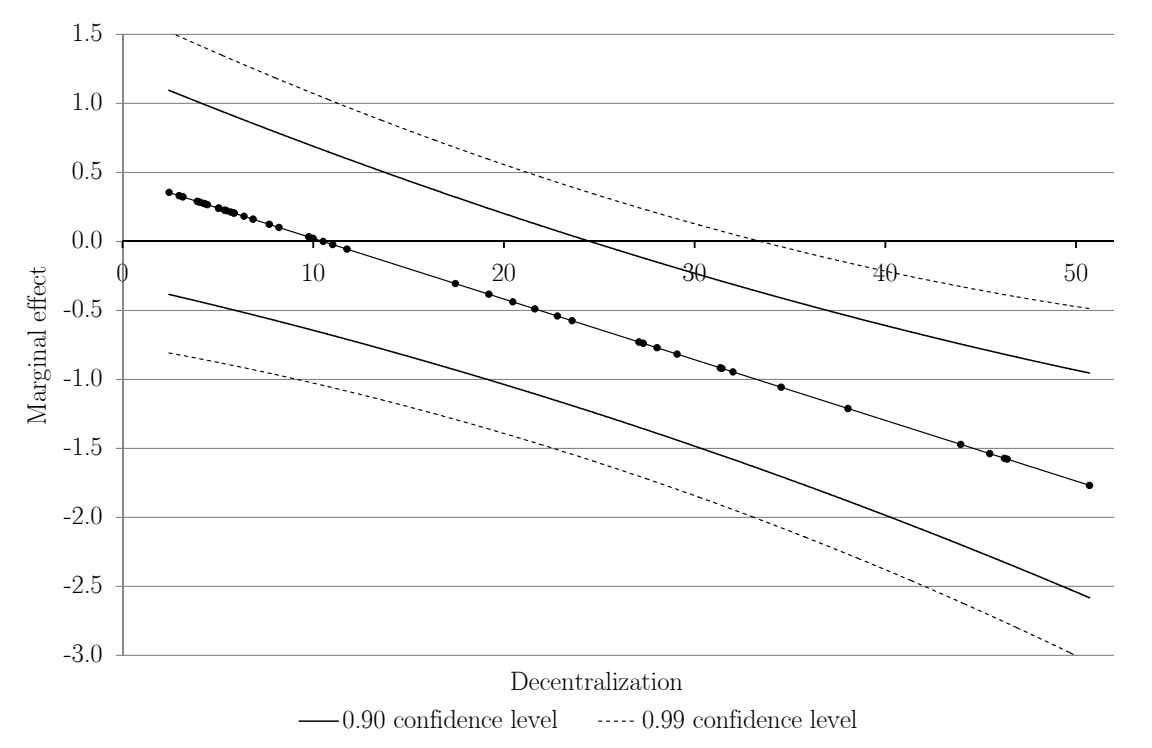

Figure 1: Marginal effect of total net ODA on growth: expenditure decentralization

The cutoff value of decentralization is the value of decentralization for which $\partial \hat{y} / \partial a i d=$ 0 is 10.52 in the fully specified regression. Our results imply that for about $50 \%$ of countries in our sample, the total net ODA is not significantly associated with economic growth. For the remaining countries, foreign aid has a negative impact on economic growth. The effect strengthens as the degree of expenditure decentralization increases. The marginal effect is statistically different from zero, with more than $90 \%(99 \%)$ confidence with a degree of expenditure decentralization exceeding roughly 
$27 \%(35 \%)$. In other words, the impact of aid on growth is significantly negative in one third of the countries in our sample. Our results imply that the total net ODA is less effective in countries with a high degree of expenditure decentralization. The efficiency-enhancing effect of fiscal decentralization is overcompensated by negative ones, as there are coordination problems, excessive regulation, administrative costs, and corruption.

Our findings are in line with Lessmann and Markwardt (2009), who show that the impact of decentralization on the aid-growth relationship is more important than the 'good policy' hypothesis proposed by Burnside and Dollar (2000). However, departing from this study, it is of interest to know whether this result varies with the measurement concept of decentralization and/or the aid modality. There are features of decentralized countries that strengthen accountability, such as local elections. Additionally, there are types of aid that are more difficult to embezzle or to waste than other ones. To study these issues, we apply similar estimations to our discussed example, using alternative decentralization measures while distinguishing between different aid types. Table 2 summarizes our results.

Table 2: Summary of estimation results

\begin{tabular}{|c|c|c|c|c|c|c|c|c|c|c|}
\hline \multirow[b]{2}{*}{ Aid type } & \multicolumn{4}{|c|}{ Fiscal decentralization } & \multicolumn{5}{|c|}{ Political decentralization } & \multirow[b]{2}{*}{ subempl } \\
\hline & expdec & revdec & vertimb & taxdec & federal & tiers & botel & auton & resid & \\
\hline grants & $-1-$ & $-/-$ & $(-/-)$ & $-/-$ & $(-/+)$ & $(-/+)$ & $(-/+)$ & $(-/+)$ & $(-/+)$ & $(-/+)$ \\
\hline loans & $(-/-)$ & $(-/-)$ & $(+/-)$ & $(-/+)$ & $(-/+)$ & $(-/+)$ & $+1-$ & $(-/+)$ & $(-/+)$ & $(+/-)$ \\
\hline technical & $(+/-)$ & $(+/-)$ & $(-/+)$ & $(+/-)$ & $(-/+)$ & $(+/-)$ & $(-/+)$ & $(-/+)$ & $(-/+)$ & $-/+$ \\
\hline human & $(-/-)$ & $(-/-)$ & $(-/-)$ & $(-/-)$ & $-1-$ & $(-/-)$ & $(-/-)$ & $(-/+)$ & $(-/-)$ & $(-1-)$ \\
\hline ODA total & $-/-$ & $-1-$ & $(-/-)$ & $-1-$ & $(-1+)$ & $(-/+)$ & $(-/+)$ & $(-/+)$ & $(-/+)$ & $(-/+)$ \\
\hline multilateral & $1-/-$ & $(-/-)$ & $-/+$ & $(-/-)$ & $(-/-)$ & $(-/-)$ & $-/+$ & $(-/-)$ & $(-/-)$ & $(-/+)$ \\
\hline bilateral & $+1-$ & $(+/-)$ & $-1+$ & $(+/-)$ & $(-/-)$ & $(-/-)$ & $-/+$ & $(-/-)$ & $(-/+)$ & $(-/+)$ \\
\hline
\end{tabular}

The table reads as follows: Each cell summarizes the result of one OLS regression combining one particular aid type (rows) with one decentralization measure (columns). The first symbol indicates the sign of the regression coefficient of the respective aid variable. The second symbol concerns the interaction term of aid and the decentralization measure. For example, "-/-" reads as the negative effect of aid on growth and negative sign of the interaction term with the decentralization measure. If the marginal effect of aid on growth is insignificant for all values of the underlying decentralization variable, the results are put in parentheses. This does not necessarily mean that the coefficient of the interaction term is insignificant. Nevertheless, this is not the relevant criterion for evaluating the impact of decentralization on aid ef- 
fectiveness. A meaningful interpretation of results is only possible in cases where the marginal effects are significant.

Let us now turn to the alternative measures of fiscal and political decentralization. The degree of expenditure decentralization (EXPDEC) has significant effects in several cases. It worsens the effectiveness of grants as well as total net ODA, irrespective of whether aid is given on a multilateral or a bilateral basis. The effects of the degree of revenue decentralization $(R E V D E C)$ are quite similar. Vertical imbalances ( $V E R$ $T I M B$ ) do not impact the relationship between a single aid type and growth, although the effect on multilateral and bilateral aid effectiveness is positive. The degree of tax decentralization $(T A X D E C)$ incorporates sub-national government autonomy to some extent. The effect on the effectiveness of grants as well as on the total net ODA is again negatively impacted by this decentralization measure. The main result from this exercise is that fiscal decentralization has a negative impact on the effectiveness of total net ODA, which is based on the negative effect on the effectiveness of grants. Keep in mind that grants are the major source of all aid types. Moreover, we are not able to identify a significant effect of fiscal decentralization on the effectiveness of types of aid other than grants.

The estimation results using measures of political decentralization can be discussed very briefly, as we find no significant marginal effects of foreign aid except in one specification: the effectiveness of bilateral aid is increased by sub-national elections $(B O T E L)$. The positive effect is in line with our expectations, as local elections strengthen government accountability. The effect is statistically significant when only bilateral aid is considered. However, if we ignore the conventional confidence levels for a moment, we find an interesting difference in the measures of fiscal decentralization in general: the sign of the interaction variable of measures of political decentralization and foreign aid is positive - although insignificant - in almost all cases. This indicates that political decentralization is, in contrast to fiscal decentralization, at least not harmful to the effectiveness of foreign aid.

The last column summarizes results using the sub-national share of public-sector employment $(S U B E M P L)$ as a decentralization measure. This is the only decentralization measure, where one of the other aid types except for grants turns out to significantly impact growth depending on the degree of decentralization. The impact of technical assistance on economic growth increases with the sub-national employment share. We plotted the marginal effect of technical assistance on growth in figure 2. In countries with a low level of decentralization, the marginal impact of technical assistance on growth is significantly negative. With a degree of decentralization exceeding $50 \%$, the negative impact of aid on growth disappears. Decentralization can thus also have a positive impact on aid effectiveness. The type of aid and the measure 
of decentralization both matter in this context.

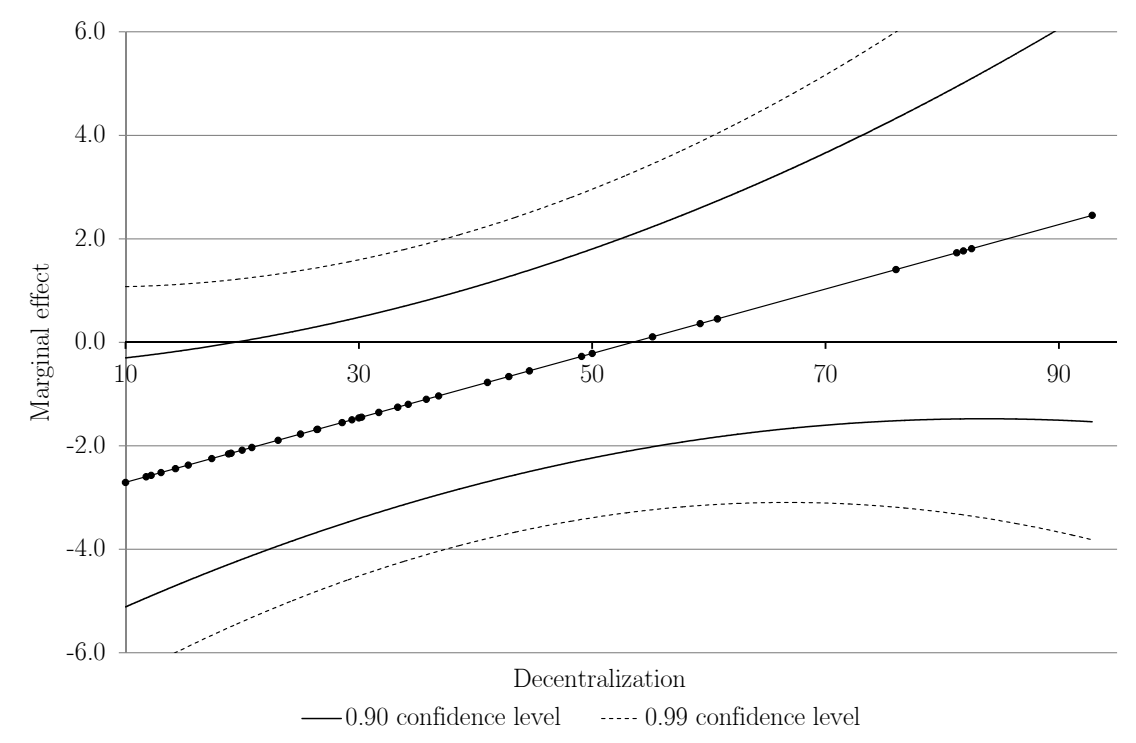

Figure 2: Marginal effect of technical aid on growth: public sector employment decentralization

Turning to the different types of aid, we cannot identify robust differences. The effectiveness of grants, being the most important modality of aid spending is impacted by measures of fiscal decentralization. Accordingly, the findings on the total net ODA look quite similar. The signs of the coefficients are also similar if we consider loans as the type of aid used. However, the effects are not statistically significant. Technical assistance is definitely less harmful for growth and may even be a positive influence. Humanitarian aid is always negatively correlated with economic growth, and the effect is worsened by decentralization. In this case, due to the apparent endogeneity problem, we do not want to stress these findings. Finally, we also cannot find meaningful differences between multilateral and bilateral aid.

\section{Summary and conclusions}

The growing literature on the effectiveness of foreign aid has thus far been unable to identify a robust direct relationship between aid and growth. Accordingly, researchers start to focus on the conditions determining the success of aid. In almost all existing studies, the federal structure as a determinant of aid effectiveness has been neglected. The aim of our paper was to close this gap in the literature and to investigate whether the growth impact of foreign aid depends on the federal structure of aid-receiving countries and/or the aid modality. 
For this purpose, we estimated the impact of different aid types on growth by considering the interdependency between aid and various decentralization measures. Our estimations are based on a panel of 72 developing countries covering the period from 1966 to 1997. The results can be summarized as follows: Measures of fiscal decentralization negatively impact the effect of aid on growth, and the results are statistically significant for grants and total net ODA. In almost all regressions, measures of political decentralization have no significant impact on the aid-growth nexus. However, the signs of the (insignificant) coefficients suggest that the relationship may be the converse. In some cases, we identify a positive impact of decentralization on aid effectiveness, such as in the case of technical assistance and the sub-national share of public sector employment. We can thus conclude that the aid modalities and the particular federal design both matter in the aid-growth relationship.

Our study provides some important implications for the design of anti-poverty programs. Both national and international development organizations consider publicsector decentralization as part of their development strategy. This is in line with our finding that most measures of decentralization have a positive impact on growth in developing countries. However, at the same time, some institutional features of decentralization undermine the effectiveness of foreign aid. Therefore, the design of anti-poverty programs should carefully consider how both instruments - foreign aid and decentralization - work together. The decentralization of public-sector employment can be a promising strategy in this context. 


\section{References}

Alesina, A., A. Devleeschauwer, W. Easterly, S. Kurlat, and R. Wacziarg (2003). Fractionalization. Journal of Economic Growth, 8(2), pp. 155-194.

Annen, K. and S. Kosempel (2009). Foreign Aid, Donor Fragmentation, and Economic Growth. The B.E. Journal of Macroeconomics, 9(1), pp. 1-30.

Banks, A. (2002). Cross-National Time-Series Data Archive. Bronx, NY: Databanks International.

Bardhan, P. (2002). Decentralization of Governance and Development. Journal of Economic Perspectives, 16, pp. 185-205.

Bardhan, P. and D. Mookherjee (2006). Decentralization and Accountability in Infrastructure Delivery in Developing Countries. Economic Journal, 116, pp. 101-127.

Beck, N. and J. Katz (1995). What to do (and not to do) with time-series cross-section data. American Political Science Review, 89(3), pp. 634-647.

Brambor, T., W. R. Clark, and M. Golder (2006). Understanding interaction models: Improving empirical analyses. Political Analysis, 14, pp. 63-82.

Brueckner, J. K. (2000). Fiscal Decentralization in Developing Countries: The Effects of Local Corruption and Tax Evasion. Annals of Economics and Finance, 1(1), pp. $1-18$.

Burnside, C. and D. Dollar (2000). Aid, Policies, and Growth. American Economic Review, 90, pp. 847-868.

Burnside, C. and D. Dollar (2004). Aid, Policies, and Growth: Reply. American Economis Review, 94(3), pp. 781-784.

Chang, C., E. Fernandez-Arias, and L. Serven (1998). Measuring aid flows: a new approach. World Bank Policy Research Working Paper No. 2050.

Dalgaard, C.-J. and H. Hansen (2001). On Aid, Growth and Good Politics. Journal of Development Studies, 37(6), pp. 17-41.

Dalgaard, C.-J., H. Hansen, and F. Tarp (2004). On the Empirics of Foreign Aid and Growth. Economic Journal, 114(496), pp. 191-216.

Davoodi, H. and H. Zou (1998). Fiscal Decentralisation and Economic Growth: A Cross Country Study. Journal of Urban Economics, 43, pp. 244-257.

Doucouliagos, H. and M. Paldam (2009a). The Aid Effectiveness Literature: The Sad Results Of 40 Years Of Research. Journal of Economic Surveys, 23(3), pp. 433-461.

Doucouliagos, H. and M. Paldam (2009b). Development Aid and Growth: An association converging to zero. Melbourne economic working paper no. 2009-17. 
Easterly, W. (2003). Can Foreign Aid Buy Growth? Journal of Economic Perspectives, 17(3), pp. 23-48.

Easterly, W., R. Levine, and D. Roodman (2004). Aid, Politics, and Growth: Comment. American Economic Review, 94(3), pp. 774-780.

Economides, G., S. Kalyvitis, and A. Philippopoulos (2008). Does Foreign Aid Distort Incentives and Hurt Growth? Theory and Evidence from 75 Aid-Recipient Countries. Public Choice, 134(3-4), pp. 463-488.

Elazar, D. J. (1995). Federalism: an overview. Pretoria: HSRC Publishers.

Fan, C. S., C. Lin, and D. Treisman (2009). Political decentralization and corruption: Evidence from around the world. Journal of Public Economics, 93(1-2), pp. 14-34.

Hansen, H. and F. Tarp (2000). Aid Effectiveness Disputed. Journal of International Development, 12(3), pp. 375-398.

Iimi, A. (2005). Decentralization and economic growth revisited: an empirical note. Journal of Urban Economics, 57(3), pp. 449-461.

Islam, M. (2005). Regime Changes, Economic Policies and the Effect of Aid on Growth. Journal of Development Studies, 41(8), pp. 1467-1492.

Kaufman, D., A. Kraay, and M. Mastruzzi (2009). Governance Matters VIII: Aggregate and Individual Governance Indicators, 1996-2008. World bank policy research working paper no. 4978.

Lessmann, C. and G. Markwardt (2009). Aid, Growth, and Devolution. CESifo Working Paper 2805.

Lessmann, C. and G. Markwardt (2010). One Size Fits all? Decentralization, Corruption, and the Monitoring of Bureaucrats. World Development, forthcoming.

Lijphart, A. (1984). Democracies. New Haven and London: Yale University Press.

Litvack, J., J. Ahmad, and R. M. Bird (1998). Rethinking decentralization in developing countries. World Bank Sector Studies Series.

McGillivray, M., S. Feeny, N. Hermes, and R. Lensink (2006). Controversies over the impact of development aid: It works; it doesn't; it can, but that depends... Journal of International Development, 18, pp. 1031-1050.

Oates, W. (1993). Fiscal decentralization and Economic Development. National Tax Journal, 46(2), pp. 237-243.

Oates, W. E. (1972). Fiscal Federalism. New York: Harcourt Brace Jovanovich.

OECD (2008). The Paris Declaration on Aid Effectiveness and the Accra Agenda for Action. OECD 2005/2008. 
Prud'homme, R. (1995). The Dangers of Decentralization. World Bank Research Observer, 10, 2, pp. 201-220.

Rajan, R. G. and A. Subramanian (2008). Aid and Grwoth: What does the CrossCountry Evidence really show? Review of Economics and Statistics, 90(4), pp. 643-665.

Rodden, J. (2004). Comparative Federalism and Decentralization: On Meaning and Measurement. Comparative Politics, 36(4), pp. 481-500.

Roodman, D. M. (2007). The Anarchy of Numbers: Aid, Development, and Crosscountry Empirics. World Bank Economic Review, 21(2), pp. 255-277.

Shleifer, A. and R. W. Vishny (1993). Corruption. Quarterly Journal of Economics, 108, pp. 599-611.

Swaroopa, V., S. Jhab, and A. S. Rajkumara (2000). Fiscal effects of foreign aid in a federal system of governance: The case of India. Journal of Public Economics, 77, pp. 307-330.

Tanzi, V. (1996). Fiscal Federalism and Decentralization: A Review of some Efficiency and Macroeconomic Aspects. In Proceedings of the Annual World Bank Conference on Development Economics 1995, pp. 295-316. Washington D.C.: The World Bank.

Treisman, D. (2002). Defining and Measuring Decentralization: A Global Perspective. Working paper university of california.

Watts, R. L. (2008). Comparing federal systems. Montréal: McGill-Queen's Univ. Press.

Weingast, B. (1995). The economic role of political institutions: Market-preserving federalism and economic development. Journal of Law, Economics and Organization, 11(1), pp. 1-31.

Woller, G. M. and K. Phillips (1998). Fiscal Decentralisation and LDC Economic Growth: An Empirical Investigation. Journal of Development Studies, 34, pp. 139148.

Worldbank (2009). World Development Indicators 2009. Technical report.

Zhang, T. and H. Zou (1998). Fiscal decentralization, public spending, and economic growth in China. Journal of Public Economics, 67(2), pp. 221-240. 
Table A.1: Data sources \& definitions

\begin{tabular}{|c|c|c|}
\hline Variable & Definition & Source \\
\hline $\begin{array}{l}\text { real per capita } \text { GDP } \\
\text { growth }\end{array}$ & $\begin{array}{l}\text { Growth rate of 4-year-averaged GDP per capita in } 2000 \$ \\
\text { prices }\end{array}$ & WDI 2006 \\
\hline Log of initial GDP & $\begin{array}{l}\text { Log of initial real GDP per capita in } 2000 \$ \text { prices at the start } \\
\text { of each period }\end{array}$ & WDI 2006 \\
\hline ethnic fractionalization & $\begin{array}{l}\text { Ethnolinguistic fractionalization is computed as one minus } \\
\text { Herfindahl index of ethnolinguistic group shares, and reflects } \\
\text { the probability that two randomly selected individuals from } \\
\text { a population belonged to different groups. }\end{array}$ & Alesina et al. (2003) \\
\hline assassinations & $\begin{array}{l}\text { Assassinations: number of assassinations per million popula- } \\
\text { tion, see Banks (2002) for details. }\end{array}$ & Easterly et al. (2004) \\
\hline institutional quality & $\begin{array}{l}\text { Mean of three governance indicators (1996): 'government ef- } \\
\text { fectiveness', 'control of corruption', and 'rule of law' }\end{array}$ & Kaufman et al. (2009) \\
\hline Log of (1+inflation) & $\begin{array}{l}\text { Log of one plus the period averaged annual inflation rate (Las- } \\
\text { peyres) }\end{array}$ & WDI 2006 \\
\hline $\begin{array}{l}\text { expenditure decentraliza- } \\
\text { tion }(E X P D E C)\end{array}$ & $\begin{array}{l}\text { The degree of expenditure decentralization relates the sum of } \\
\text { sub-national (state \& local) government expenditures to total } \\
\text { government expenditures. }\end{array}$ & $\begin{array}{l}\text { IMF Government } \mathrm{Fi}- \\
\text { nance Statistics }\end{array}$ \\
\hline $\begin{array}{l}\text { revenue decentralization } \\
(R E V D E C)\end{array}$ & $\begin{array}{l}\text { The degree of revenue decentralization relates the sum of sub- } \\
\text { national (state \& local) government revenues to total govern- } \\
\text { ment revenues. }\end{array}$ & $\begin{array}{l}\text { IMF Government Fi- } \\
\text { nance Statistics }\end{array}$ \\
\hline $\begin{array}{l}\text { vertical imbalances } \\
(V E R T I M B)\end{array}$ & Grant-share of sub-national government expenditures & $\begin{array}{l}\text { IMF Government } \\
\text { nance Statistics }\end{array}$ \\
\hline $\begin{array}{l}\operatorname{tax} \quad \text { decentralization } \\
(T A X D E C)\end{array}$ & $\begin{array}{l}\text { Share of sub-national government tax revenues in total go- } \\
\text { vernment revenues }\end{array}$ & $\begin{array}{l}\text { IMF Government } \\
\text { nance Statistics }\end{array}$ \\
\hline federal $(F E D E R A L)$ & Dummy for countries with a federal constitution & $\begin{array}{l}\text { Treisman }(2002) \\
\text { Elazar }(1995)\end{array}$ \\
\hline vertical tiers $(T I E R S)$ & Number of vertical government tiers & $\begin{array}{l}\text { Treisman }(2002) \\
\text { Fan et al. }(2009)\end{array}$ \\
\hline local elections (BOTEL) & $\begin{array}{l}\text { Dummy variable, which is one if a country has elections at } \\
\text { the lowest or second lowest tier of government. }\end{array}$ & $\begin{array}{l}\text { Treisman }(2002) \\
\text { Fan et al. }(2009)\end{array}$ \\
\hline local autonomy $(A U T O N)$ & $\begin{array}{l}\text { Local jurisdictions have a certain amount of 'autonomy' re- } \\
\text { garding a given question, if the constitution reserves exclusive } \\
\text { decision-making power on that question. }\end{array}$ & $\begin{array}{l}\text { Treisman }(2002) \\
\text { Fan et al. }(2009)\end{array}$ \\
\hline $\begin{array}{l}\text { residual } \\
(R E S I D)\end{array}$ & $\begin{array}{l}\text { A sub-national legislature is said to have 'residual authority', } \\
\text { if the constitution assigns the exclusive right to legislate on } \\
\text { issues that are not specifically assigned to one level of govern- } \\
\text { ment. }\end{array}$ & $\begin{array}{l}\text { Treisman }(2002) \\
\text { Fan et al. }(2009)\end{array}$ \\
\hline $\begin{array}{l}\text { employment decentraliza- } \\
\text { tion }(S U B E M P L)\end{array}$ & $\begin{array}{l}\text { Share of sub-national government employment in total govern- } \\
\text { ment employment }\end{array}$ & ILO LABORSTA \\
\hline
\end{tabular}

Table A.2: Summary statistics

\begin{tabular}{|c|c|c|c|c|c|}
\hline & Observations & Mean & Std. Dev. & Maximum & Minimum \\
\hline real per capita GDP growth & 669 & 0.068 & 0.142 & 0.773 & -0.526 \\
\hline Log of initial GDP & 789 & 3760.655 & 3584.693 & 27761.900 & 418.556 \\
\hline ethnic fractionalization & 864 & 0.494 & 0.251 & 0.930 & 0.002 \\
\hline assassinations & 530 & 0.268 & 0.799 & 9.750 & 0.000 \\
\hline institutional quality & 864 & 2.189 & 0.624 & 4.596 & 1.154 \\
\hline inflation & 649 & 42.945 & 210.550 & 3357.528 & -3.242 \\
\hline EXPDEC & 552 & 17.259 & 14.511 & 50.707 & 2.439 \\
\hline REVDEC & 552 & 13.917 & 13.272 & 51.436 & 1.176 \\
\hline VERTIMB & 456 & 35.303 & 27.157 & 98.122 & 0.139 \\
\hline TAXDEC & 492 & 7.520 & 9.409 & 47.187 & 0.028 \\
\hline FEDERAL & 864 & 0.111 & 0.314 & 1.000 & 0.000 \\
\hline TIERS & 864 & 3.833 & 1.065 & 6.000 & 1.000 \\
\hline BOTEL & 564 & 0.670 & 0.465 & 1.000 & 0.000 \\
\hline AUTON & 852 & 0.113 & 0.316 & 1.000 & 0.000 \\
\hline RESID & 852 & 0.099 & 0.298 & 1.000 & 0.000 \\
\hline SUBEMPL & 504 & 36.939 & 21.597 & 92.857 & 10.000 \\
\hline grants & 584 & 0.030 & 0.038 & 0.270 & 0.000 \\
\hline loans & 584 & 0.003 & 0.010 & 0.093 & -0.094 \\
\hline technical & 584 & 0.011 & 0.013 & 0.077 & 0.000 \\
\hline human & 455 & 0.003 & 0.006 & 0.070 & -0.001 \\
\hline total net ODA & 739 & 0.053 & 0.065 & 0.417 & -0.006 \\
\hline multilateral & 341 & 0.660 & 0.991 & 8.379 & -0.064 \\
\hline bilateral & 347 & 1.470 & 1.837 & 11.909 & 0.000 \\
\hline
\end{tabular}




\section{CESifo Working Paper Series}

for full list see www.cesifo-group.org/wp

(address: Poschingerstr. 5, 81679 Munich, Germany, office@cesifo.de)

2973 Magnus Söderberg, Informal Benchmarks as a Source of Regulatory Threat in Unregulated Utility Sectors, March 2010

2974 Piotr Wdowiński and Marta Malecka, Asymmetry in Volatility: A Comparison of Developed and Transition Stock Markets, March 2010

2975 Frans van Winden, Michal Krawczyk and Astrid Hopfensitz, Investment, Resolution of Risk, and the Role of Affect, March 2010

2976 Hyun-Ju Koh and Nadine Riedel, Do Governments Tax Agglomeration Rents?, March 2010

2977 Johann K. Brunner and Susanne Pech, Optimum Taxation of Bequests in a Model with Initial Wealth, March 2010

2978 Guglielmo Maria Caporale and Nicola Spagnolo, Stock Market Integration between three CEECs, Russia and the UK, March 2010

2979 Florian Englmaier, Ales Filipi and Ravi Singh, Incentives, Reputation and the Allocation of Authority, March 2010

2980 Konstantinos Angelopoulos, George Economides and Apostolis Philippopoulos, What is the Best Environmental Policy? Taxes, Permits and Rules under Economic and Environmental Uncertainty, March 2010

2981 Frederick van der Ploeg, Rapacious Resource Depletion, Excessive Investment and Insecure Property Rights, March 2010

2982 Wolfram F. Richter and Christoph Braun, Efficient Subsidization of Human Capital Accumulation with Overlapping Generations and Endogenous Growth, March 2010

2983 Francesco Cinnirella, Marc Piopiunik and Joachim Winter, Why Does Height Matter for Educational Attainment? Evidence from German Pre-Teen Children, March 2010

2984 Bernard Van Praag, Well-being Inequality and Reference Groups - An Agenda for New Research, March 2010

2985 Francesca Barion, Raffaele Miniaci, Paolo M. Panteghini and Maria Laura Parisi, Profit Shifting by Debt Financing in Europe, March 2010

2986 Alexander Haupt and Magdalena Stadejek, The Choice of Environmental Policy Instruments: Energy Efficiency and Redistribution, March 2010

2987 John Komlos and Marek Brabec, The Trend of BMI Values among US Adults, March 2010 
2988 Emanuele Massetti and Lea Nicita, The Optimal Climate Policy Portfolio when Knowledge Spills across Sectors, March 2010

2989 Helmut Rainer and Thomas Siedler, Family Location and Caregiving Patterns from an International Perspective, March 2010

2990 Toru Kikuchi and Ngo Van Long, A Simple Model of Service Offshoring with Time Zone Differences, March 2010

2991 Assaf Razin, Efraim Sadka and Benjarong Suwankiri, Migration and the Welfare State: Dynamic Political-Economy Theory, March 2010

2992 Bård Harstad, Buy Coal! Deposit Markets Prevent Carbon Leakage, March 2010

2993 Axel Dreher, Stephan Klasen, James Raymond Vreeland and Eric Werker, The Costs of Favoritism: Is Politically-driven Aid less Effective?, March 2010

2994 Sven Neelsen and Thomas Stratmann, Effects of Prenatal and Early Life Malnutrition: Evidence from the Greek Famine, March 2010

2995 Claude Hillinger and Bernd Süssmuth, The Quantity Theory of Money: An Assessment of its Real Linchpin Prediction, March 2010

2996 Matthew M. Chingos and Martin R. West, Do More Effective Teachers Earn More Outside of the Classroom?, March 2010

2997 Laurence Jacquet and Dirk Van de gaer, A Comparison of Optimal Tax Policies when Compensation or Responsibility Matter, March 2010

2998 Valentina Bosetti, Carlo Carraro, Romain Duval and Massimo Tavoni, What Should we Expect from Innovation? A Model-Based Assessment of the Environmental and Mitigation Cost Implications of Climate-Related R\&D, March 2010

2999 Scott Alan Carson, Nineteenth Century Stature and Family Size: Binding Constraint or Productive Labor Force?, March 2010

3000 Jukka Pirttilä and Ilpo Suoniemi, Public Provision, Commodity Demand and Hours of Work: An Empirical Analysis, March 2010

3001 Bertrand Candelon and Franz C. Palm, Banking and Debt Crises in Europe: The Dangerous Liaisons?, March 2010

3002 Joan Costa-i-Font and Marin Gemmill-Toyama, Does Cost Sharing really Reduce Inappropriate Prescriptions?, March 2010

3003 Scott Barrett, Climate Treaties and Backstop Technologies, March 2010

3004 Hans Jarle Kind, Tore Nilssen and Lars Sørgard, Price Coordination in Two-Sided Markets: Competition in the TV Industry, March 2010 
3005 Jay Pil Choi and Heiko Gerlach, Global Cartels, Leniency Programs and International Antitrust Cooperation, March 2010

3006 Aneta Hryckiewicz and Oskar Kowalewski, Why do Foreign Banks Withdraw from other Countries? A Panel Data Analysis, March 2010

3007 Eric A. Hanushek and Ludger Woessmann, Sample Selectivity and the Validity of International Student Achievement Tests in Economic Research, March 2010

3008 Dennis Novy, International Trade and Monopolistic Competition without CES: Estimating Translog Gravity, April 2010

3009 Yin-Wong Cheung, Guonan Ma and Robert N. McCauley, Renminbising China's Foreign Assets, April 2010

3010 Michel Beine and Sara Salomone, Migration and Networks: Does Education Matter more than Gender?, April 2010

3011 Friedrich Schneider, Tilman Brück and Daniel Meierrieks, The Economics of Terrorism and Counter-Terrorism: A Survey (Part I), April 2010

3012 Friedrich Schneider, Tilman Brück and Daniel Meierrieks, The Economics of Terrorism and Counter-Terrorism: A Survey (Part II), April 2010

3013 Frederick van der Ploeg and Steven Poelhekke, The Pungent Smell of "Red Herrings": Subsoil Assets, Rents, Volatility and the Resource Curse, April 2010

3014 Vjollca Sadiraj, Jan Tuinstra and Frans van Winden, Identification of Voters with Interest Groups Improves the Electoral Chances of the Challenger, April 2010

3015 Guglielmo Maria Caporale, Davide Ciferri and Alessandro Girardi, Time-Varying Spot and Futures Oil Price Dynamics, April 2010

3016 Scott Alan Carson, Racial Differences in Body-Mass Indices for Men Imprisoned in $19^{\text {th }}$ Century US Prisons: A Multinomial Approach, April 2010

3017 Alessandro Fedele, Paolo M. Panteghini and Sergio Vergalli, Optimal Investment and Financial Strategies under Tax Rate Uncertainty, April 2010

3018 Laurence Jacquet, Take it or Leave it: Take-up, Optimal Transfer Programs, and Monitoring, April 2010

3019 Wilhelm Kohler and Jens Wrona, Offshoring Tasks, yet Creating Jobs?, April 2010

3020 Paul De Grauwe, Top-Down versus Bottom-Up Macroeconomics, April 2010

3021 Karl Ove Aarbu, Demand Patterns for Treatment Insurance in Norway, April 2010

3022 Toke S. Aidt and Jayasri Dutta, Fiscal Federalism and Electoral Accountability, April 2010 
3023 Bahram Pesaran and M. Hashem Pesaran, Conditional Volatility and Correlations of Weekly Returns and the VaR Analysis of 2008 Stock Market Crash, April 2010

3024 Stefan Buehler and Dennis L. Gärtner, Making Sense of Non-Binding Retail-Price Recommendations, April 2010

3025 Leonid V. Azarnert, Immigration, Fertility, and Human Capital: A Model of Economic Decline of the West, April 2010

3026 Christian Bayer and Klaus Wälde, Matching and Saving in Continuous Time: Theory and 3026-A Matching and Saving in Continuous Time: Proofs, April 2010

3027 Coen N. Teulings and Nick Zubanov, Is Economic Recovery a Myth? Robust Estimation of Impulse Responses, April 2010

3028 Clara Graziano and Annalisa Luporini, Optimal Delegation when the Large Shareholder has Multiple Tasks, April 2010

3029 Erik Snowberg and Justin Wolfers, Explaining the Favorite-Longshot Bias: Is it RiskLove or Misperceptions?, April 2010

3030 Doina Radulescu, The Effects of a Bonus Tax on Manager Compensation and Welfare, April 2010

3031 Helmut Lütkepohl, Forecasting Nonlinear Aggregates and Aggregates with Timevarying Weights, April 2010

3032 Silvia Rocha-Akis and Ronnie Schöb, Welfare Policy in the Presence of Unionised Labour and Internationally Mobile Firms, April 2010

3033 Steven Brakman, Robert Inklaar and Charles van Marrewijk, Structural Change in OECD Comparative Advantage, April 2010

3034 Dirk Schindler and Guttorm Schjelderup, Multinationals, Minority Ownership and TaxEfficient Financing Structures, April 2010

3035 Christian Lessmann and Gunther Markwardt, Decentralization and Foreign Aid Effectiveness: Do Aid Modality and Federal Design Matter in Poverty Alleviation?, April 2010 